\title{
And now, the rescission of DACA...
}

\author{
Lourdes Torres ${ }^{1}$
}

Undocumented youth around the country courageously came out of the shadows in the early 2000s to make their plight known. They risked incarceration and deportation by speaking out, protesting, and engaging in creative, attentiongenerating direct actions. They denounced both the inaction of the government and the tepid approach of mainstream Latino organizations advocating for immigration reform. By bravely putting a human face on their stories and loudly demanding inclusion, they shifted immigration debates, lobbied relentlessly for their cause, and shamed President Obama into taking action on their behalf.

Now, the current US administration sows fear and anxiety with its stepped-up immigration raids, the presidential pardon of the racist Maricopa County, Arizona, sheriff Joe Arpaio, and soon after, the rescission of the 2012 Deferred Action for Childhood Arrivals (DACA) program. Also under threat are thousands of Brown and Black immigrants from Central America, Haiti, Sudan, Somalia and other countries who currently have Temporary Protective Status (TPS).

DACA, created through executive order by Barak Obama in 2012 after fierce lobbying from youth activists, although not ideal, has given approximately 800,000 undocumented young people a temporary reprieve from deportation. Those who applied for DACA, paid the $\$ 495$ fee, and successfully met the program's criteria (are under the age of 31 as of June 15, 2012; entered the United States prior to age sixteen, resided in the United States since June 15, 2007, are in school or the military, and have no criminal history) gained the ability to obtain a work permit, and in many cases, a driver's license, and college enrollment with in-state tuition. Those approved for DACA had been protected from deportation for a 2-year period with the possibility of renewal for another 2 years.

Lourdes Torres

ltorres@depaul.edu

1 DePaul University, Chicago, IL, USA 
About half of the people eligible for DACA took part in this program. This small group represents about $7 \%$ of the roughly eleven million undocumented people in the US. While the majority of DACA recipients are Mexican $(78 \%)$ or Central American (8\%), other recipients come from Brazil, Jamaica, South Korea, Poland, Pakistan, India, and several other countries (https://www.uscis.gov/).

The power of the DREAMer narrative is difficult to deny even by antiimmigration hawks. These are hardworking, successful youth who have taken what little this country has offered them and are working tirelessly to build a future, despite their uncertain, temporary status. Condemnation of the cruel rescission of DACA has been swift and, surprisingly, has come from all sides, including some Republican members of Congress. This has led to the anticipation that a legislative fix is within reach within the next 6 months, after which the program will be terminated.

Many DREAMers, however, are leery of possible legislation that would link a DREAMer bill to enhanced immigration enforcement measures and further militarization of the border. They have made it clear that they are not interested in gaining their safety, or even the possibility of a path to citizenship, at the expense of their parents and other undocumented people who don't meet the narrow criteria of DACA. They do not want to secure their future if it means the escalation of deadly and punishing immigration enforcement against the other ten million undocumented immigrants in the United States. They are not interested in throwing their parents, families, friends and others who did not and will not qualify for DACA under the proverbial bus. DREAMers themselves have shifted their analysis away from a narrative of innocence which juxtaposes their situation with that of their parents and other immigrants in this country who have not had access to education or signed up for military service. Many insist on fighting for a comprehensive, humane immigration policy for all.

These DREAMers remind us of the worth of all undocumented immigrants, not only as innocents or work horses who "get the job done," but also as human beings who are in the United States due to the "harvest of empire" and who deserve the right to live decent and dignified lives. They remind us that even immigrants who may have made a mistake or aren't in college or the military deserve the chance to build a life for themselves and their families in the United States.

Progressive youth organizations are once again providing a response to the intensifying assault on immigrants and other people of color. They are connecting the dots between the administration's attack on immigrants and the attack on Muslims, African Americans, transgender people, and women's reproductive freedom and rights. They provide a powerful example of the way forward through the coalitional work they are spearheading to resist the damaging administrative agenda that has only just begun to roll out.

We would do well to follow the lead of youth engaged in coalitional politics and organizing. Two great examples of organizations pursuing this path are Mijente (https://mijente.net/) and The Black Youth Project 100 (http://byp100.org/). They share an intersectional analysis and work across communities to resist white supremacy at every level. 
Mijente, founded in Chicago in 2015, aims to build a national Latino movement with an agenda that is pro-organizing, pro-Black, pro-indigenous, and pro-queer and trans. They seek to organize Latinos and work in partnership with like-minded progressive groups to create social change. BYP 100 was launched 5 years ago when George Zimmerman was freed despite killing Trayvon Martin; the organization is working to organize black youth. Originating in Chicago, there are now eight BYP 100 chapters. Using a Black feminist and queer analysis, these activists work to dismantle the prison industrial complex, and expand the rights of people of color, women, and LGBTQ people.

These organizations are engaged in multiple social justice campaigns and are working together on issues including contesting the mass incarceration of Black and Latino people and advocating for humane immigration reform. They support direct action campaigns that empower people to engage in political work to advance social justice for themselves and other disenfranchised communities. As in the past, today we would do well to follow the lead of these youth who demonstrate that solidarity across identity groups and direct action offer a clear path to movement building and unified resistance. We cannot afford to be spectators in this struggle. 